\title{
Improving the nematicidal potential of Bacillus amyloliquefaciens and Lysinibacillus sphaericus against the root-knot nematode Meloidogyne incognita using protoplast fusion technique
}

\author{
M. S. Abdel-Salam¹, Hoda H. Ameen², Gaziea M. Soliman², U. S. Elkelany² and Amira M. Asar ${ }^{3}$
}

\begin{abstract}
Root-knot nematodes (RKNs) are one of the major constraints of vegetable cultivation worldwide. Chemical nematicides, the primary management tool for over 50 years, have a negative impact on the environment and the ineffectiveness after prolonged use. Biological control using eco-friendly rhizosphere bacteria antagonistic to nematodes is one of the alternative approaches. The objective of this study was to improve the nematicidal activity of Bacillus amyloliquefaciens subsp. plantarum SA5 and Lysinibacillus sphaericus Amira strain against RKN Meloidogyne incognita, using the protoplast technique. Their fusants were tested for their chitinase and nematicidal activity using bioassay and greenhouse experiments. The selected fusants from the two bacterial strains were more effective in killing $M$. incognita $\mathrm{J}_{2}$ under laboratory conditions. Percentage mortality after $24 \mathrm{~h}$ of exposure were $70.85,84.69,95.56,94.99,100$, and $89.46 \%$ due to the parental strains B. amyloliquefaciens and L. sphaericus and the fusants Bas3, Bas6-2, Bas8, and Bas11, respectively. There was a positive correlation between the chitinase production and the nematicidal effect of the bacterial strains. Under greenhouse conditions, Bas 8 which produced the highest amount of chitinase induced the greatest reduction in nematode counts and gave the best results in shoot length and fresh and dry weights as compared to control. Chitinase production of fusant was much higher under solid-state fermentation (SSF) than submerged fermentation conditions. The recorded chitinase produced by B. amyloliquefaciens, L. sphaericus, and Bas8 were 0,1393, and 3399 units ( $\mu \mathrm{g} \mathrm{NAG/ml} \mathrm{enzyme/h),}$ respectively, under solid-state fermentation and 90,85 , and 143 units ( $\mu \mathrm{g} \mathrm{NAG/ml} \mathrm{enzyme/h),} \mathrm{respectively,} \mathrm{under}$ submerged fermentation conditions. Protoplast fusion was a powerful technique in improving nematicidal activity. Chitinase production is an important factor in improving the nematicidal activity of such microorganisms. The obtained improved fusant could be used as a biological control agent for M. incognita.
\end{abstract}

Keywords: Meloidogyne incognita, Biological control, Bacillus amyloliquefaciens, Lysinibacillus sphaericus, Protoplast fusion, Chitinase

\footnotetext{
* Correspondence: hoda_ameen@yahoo.co.uk

2Plant Pathology Department, National Research Centre, Giza, Egypt

Full list of author information is available at the end of the article
} 


\section{Background}

Meloidogyne spp. [root-knot nematodes (RKNs)] are one of the major constraints of vegetable cultivation worldwide, mainly in light soil and warm regions; their losses reached about US\$125 billion yearly (Chitwood 2003). Nematode management depends mainly on chemical nematicides, but due to their negative impact on the environment and the ineffectiveness after prolonged use, nematologists have to innovate safer and eco-friendly control methods. Biological control, using rhizosphere bacteria, has been reported to be effective in improving plant growth and affect nematodes' reproduction through different mechanisms involving production of plant growth hormones, enhancing nitrogen fixing ability and mineral availability in soil (Saharan and Nehra 2011), and producing metabolites and enzymes that act directly against nematodes (Becker et al. 1988). Chitin represents a major structural component of many plant pathogens, including nematodes (Yang et al. 2013). Chitinases (EC 3.2.1.14) hydrolyze the $\beta$-1,4-linkages in chitin. The enzymatic digestion or deformation of the chitin component of nematode organisms by chitinase could be an effective method for their control. Several results suggest that chitinase interfered with the hatching of Meloidogyne sp. eggs resulting in the early emergence of juveniles that were less able to survive in soil (Mercer et al. 1992 and Woo-Jin et al. 2002). Studies on optimization of chitinases have been reported earlier with the effects of different medium ingredients on its production. Solid-state fermentation (SSF) has emerged as an appropriate technology for the management of agro-industrial residues and for their added value (Tunga et al. 1998). Different types of substrates, which contain chitin, have been tried for the production of chitinase (Sudhakar and Nagarajan 2010).

Researchers observed that the soils that suppress nematode multiplication contain a range of nematode enemies that attack different RKN stages of the life cycle. Many nematologists consider that more effective control and more success can be achieved by combining more than one bioagent. The establishment of different microorganisms may find some difficulties, because in certain cases, mixtures of different strains have no synergistic effect due to their different nutritional and environmental requirements. Further, a mixture that improves potency under one set of conditions or on one host may not perform under different conditions (Schisler et al. 1997). Such findings open the door for using the recombinant DNA technology in the construction of strain that combines all the desired properties through some biotechnological procedures like protoplast fusion between different bioagents.

The aim of this study was to improve the nematicidal potential of Bacillus amyloliquefaciens and Lysinibacillus sphaericus using protoplast fusion technique and assess their potential as biological control agents against $M$. incognita under laboratory and greenhouse conditions.

\section{Materials and methods \\ Bacterial strains}

Bacillus amyloliquefaciens subsp. plantarum SA5, Microbial Genetics Dept., NRC (GenBank accession number: KC429571.1), and Lysinibacillus sphaericus Amira strain, Microbial Chemistry Dept., NRC (GenBank accession number: KT361851.1), were evaluated.

\section{Medium and growth conditions}

A Luria-Bertani (LB) medium was used for bacterial growth (Davis et al. 1980). Growth temperature was $37^{\circ} \mathrm{C}$. The following concentrations of antibiotics were used $\left(\mu \mathrm{g} \mathrm{ml}^{-1}\right.$ ) when required: ampicillin (AP) 100, chloramphenicol (CM) 50, neomycin (NM) 100, rifampicin (RF) 150, streptomycin (SM) 400, and tetracycline (TC) 10.

\section{Protoplast fusion Antibiotic resistance pattern}

Antibiotic resistance pattern of B. amyloliquefaciens or L. sphaericus was evaluated, using disc diffusion method (REF). Overnight cultures of the tested strains were swabbed onto plates of LB agar medium and allowed to dry. Antibiotic discs were placed on the agar surface, and the plates were incubated for $24 \mathrm{~h}$ at $37^{\circ} \mathrm{C}$.

\section{Induction of genetic markers}

Spontaneous antibiotic-resistant mutants of L. sphaericus or B. amyloliquefaciens were isolated by increasing the concentration of ampicillin (Ap), streptomycin (Sm), chloramphenicol $(\mathrm{Cm})$, kanamycin $(\mathrm{Km})$, rifampicin (Rif), tetracycline (Tc), and erythromycin (Erm) resistance in selective media (Ibrahim et al. 1998).

\section{Protoplast preparation}

B. amyloliquefaciens SA5 or L. sphaericus were inoculated in 500-ml flasks containing $70 \mathrm{ml}$ of LB broth medium and incubated at $37^{\circ} \mathrm{C}$ for $24 \mathrm{~h}$ at $120 \mathrm{rpm}$. One milliliter from each culture was added to $20 \mathrm{ml} \mathrm{LB}$ broth and incubated for $4 \mathrm{~h}$ at $120 \mathrm{rpm}$. Cells were harvested by centrifugation at $5000 \mathrm{rpm}$ for $10 \mathrm{~min}$ and washed once with $1 \% \mathrm{~N}$-laurylsarcosine, followed by washing three times with an osmotic stabilizer buffer (Tris- $\mathrm{HCl}$ with $\mathrm{MgSO}_{4}$ ). The bacterial cells were then pelleted by centrifugation. Lysozyme was dissolved in osmotic stabilizer buffer $5 \mathrm{mg} \mathrm{ml}^{-1}$, sterilized by a $0.2-\mu \mathrm{m}$ millipore filter. One milliliter of lysozyme was added to the cell pellet of each parental strain and mixed thoroughly to make a suspension. The resulting mixture was incubated at $37{ }^{\circ} \mathrm{C}$ up to $2 \mathrm{~h}$ on a water bath. Protoplast formation was confirmed periodically by phase contrast microscope observation and by 
osmotic shock $(0.1 \mathrm{ml}$ suspension was diluted tenfold in distilled water) and optical density (OD) measured at $600 \mathrm{~nm}$ using a spectrophotometer (Eisa et al. 1995).

\section{Protoplast fusion}

One milliliter of L. sphaericus or B. amyloliquefaciens protoplasts was mixed and centrifuged at $2000 \mathrm{rpm}$ for $10 \mathrm{~min}$. Then, $1 \mathrm{ml}$ of 30\% PEG 6000 in $100 \mathrm{mM}$ $\mathrm{CaCl}_{2}$ was added and incubated at $30{ }^{\circ} \mathrm{C}$ for $1 \mathrm{~h}$ (Hopwood et al. 1985) and then washed three times with $5 \mathrm{ml}$ Tris- $\mathrm{HCl}$ with mannitol buffer, centrifuged for $10 \mathrm{~min}$ at $1000 \mathrm{rpm}$, and resuspended in $2 \mathrm{ml}$ Tris- $\mathrm{HCl}$ with mannitol buffer. A sample of $100 \mu \mathrm{l}$ was added to a soft agar medium containing an osmotic stabilizer (Tris- $\mathrm{HCl}$ with mannitol), overlaid on the selective basal medium (containing different antibiotics), and incubated at $37{ }^{\circ} \mathrm{C}$ for up to 3 days to select the fusants. The concentrations of each parental protoplast were doubled (i.e., $2 \mathrm{ml}$ of each), using the same procedure to detect any spontaneous resistance of the selected antibiotics used.

\section{Chitinase assay}

Chitinase activity was assayed by dinitrosalicylic acid (DNS) method (Sudhakar and Nagarajan 2010) that determining NAG ( $N$-acetyl-glucosamine) as the final product of hydrolysis colloidal chitin solution. One unit $(\mathrm{U})$ of the chitinase activity was defined as the amount of enzyme required to release $1 \mu \mathrm{g}$ of NAG [from $0.5 \%(w / v)$ of the substrate colloidal chitin solution]/milliliter of chitinase enzyme solution/hour, under assay conditions.

\section{Evaluating the nematicidal potential of bacterial strains against Meloidogyne incognita Bioassay test}

Meloidogyne incognita eggs were extracted from the infected eggplant roots; according to Hussey and Barker (1973), the egg suspension was incubated at room temperature for egg hatching. Hatched, second-stage juveniles were collected after 4 days and rinsed with sterile distilled water, and the inoculum concentrations of $\mathrm{J}_{2}$ were adjusted to 50 juveniles $\mathrm{ml}^{-1}$. In a $6-\mathrm{cm}$ diam Petri dish, $4 \mathrm{ml}$ of nematode suspension was added to $1 \mathrm{ml}\left(2 \times 10^{6} \mathrm{cfu} \mathrm{ml}^{-1}\right)$ from the following bacterial strains B. amyloliquefaciens, L. sphaericus, Bas3, Bas6-2, Bas8, and Bas11. One milliliter of distilled water instead of bacterial suspension was served as control. Four repetitions from each treatment were performed; all dishes were kept at room temperature $\left(30{ }^{\circ} \mathrm{C}\right)$. The number of surviving and dead individuals was counted after $24 \mathrm{~h}$ using a 1-ml Hawksley counting slide. After the exposure period, the nematodes in each treatment were moved to distilled water and left for
$24 \mathrm{~h}$ to observe whether immobile nematodes resumed activity or not. Percentage mortality was calculated according to Mortality $\%=[\mathrm{C} 1-\mathrm{C} 2 / \mathrm{C} 1] \times 100$ where $\mathrm{C} 1$ is the number of live nematode larvae in control treatment and $\mathrm{C} 2$ is the number of live nematode larvae counted in each treatment.

\section{Greenhouse experiment}

The nematicidal activity of Bas 8 was evaluated against M. incognita infecting tomato plants in comparison with its parents under greenhouse conditions. Fifteencentimeter-diam plastic pots were filled with $1 \mathrm{~kg}$ autoclaved mixed soil with loamy sand-clay $(1: 1 \mathrm{v} / \mathrm{v})$. One-month-old tomato seedlings of Solanum lycopersicum were transplanted to the center of each pot (one seedling per pot). Three days after transplantation, the soil was drenched with $10 \mathrm{ml}$ suspension $\left(2 \times 10^{6} \mathrm{cfu} \mathrm{ml}^{-1}\right)$ of actively growing cultures of $B$. amyloliquefaciens alone, L. sphaericus alone, B. amyloliquefaciens and L. sphaericus in combination, and Bas 8 as one-time drench simultaneously with 2000 freshly hatched second-stage juveniles of $M$. incognita in three holes around the root of each seedling. Each treatment was replicated five times. Pots inoculated with nematode only without bacteria served as control. Plants were watered slightly after inoculation and thereafter, whenever required. The experiment was set in a complete randomized design on the greenhouse bench at $35{ }^{\circ} \mathrm{C}$. The experiment was terminated 60 days after nematode inoculation. Data on nematode reproduction and plant growth parameters were recorded and were subjected to analysis of variance (ANOVA) and means compared according to Duncan's multiple range test (Duncan 1955).

\section{Results and discussion}

Antibiotic resistance of parental strains

Antibiotic resistance pattern of parental bacterial strains L. sphaericus or B. amyloliquefaciens was evaluated using a disc diffusion method. Results indicated that both strains were sensitive to almost all tested antibiotics used.

\section{Induction of genetic markers}

Different antibiotic-resistant mutants were successfully isolated from both parental strains. Among them, two were selected for protoplast fusion trials, i.e., L. sphaericus $\mathrm{Km} 1$ and $B$. amyloliquefaciens Ap2. The antibiotic resistance pattern of $L$. sphaericus $\mathrm{Km} 1$ was $\mathrm{Sm}^{\mathrm{r}}, \mathrm{Km}^{\mathrm{r}}$, $\mathrm{Tc}^{\mathrm{r}}$, and $\mathrm{Cm}^{\mathrm{r}}$ and that of B. amyloliquefaciens Ap2 was $A p^{r}$ and $T c^{r}$, respectively. 


\section{Protoplast induction and fusant isolation}

Protoplast formation was confirmed by phase contrast microscope observation every $15 \mathrm{~min}$ of incubation with lysozyme and by $\mathrm{OD}_{600}$ after osmotic shock. The lowest $\mathrm{OD}_{600}$ reading was after $2 \mathrm{~h}$ of incubation with the enzyme. Both streptomycin and ampicillin were added to LB medium as the selective medium, where streptomycin will prevent the growth of $B$. amyloliquefaciens Ap2 and ampicillin will prevent the growth of L. sphaericus $\mathrm{Km} 1$. Only fusant strains combined the two antibiotic resistance genes grew. Double concentrations of parental protoplast did not produce any colony at the selective conditions, while mixing the parental protoplasts resulted in 11 colonies. They were isolated and tested for their ability to grow with different antibiotics (Table 1).

Although all the 11 fusants were selected on LB medium supplemented with both streptomycin and ampicillin, only five could regrow with the two antibiotics. Five of the other fusants could not regrow with ampicillin, and one fusant (Bas10) could not regrow with both antibiotics. These results reflected the genetic stability among the tested fusants according to the antibiotic resistance genes to be about $45.5 \%$. Results showed also that fusant Bas 11 had different morphological shapes where it was almost a colorless colony. During an antibiotic resistance pattern test, the fusant Bas6 produced two large colonies (segregants), which could grow with both streptomycin and ampicillin. They were isolated and named Bas6-1 and Bas6-2. The two segregants were retested with all antibiotics. Results indicated stability of fusant Bas6-2, where

Table 1 Antibiotic resistance patterns of parental strains and their fusants

\begin{tabular}{lllll}
\hline Parental and fusants & $\mathrm{Ap}$ & $\mathrm{Sm}$ & $\mathrm{Cm}$ & $\mathrm{Km}$ \\
\hline L. sphaericus & - & +++ & +++ & +++ \\
B. amyloliquefaciens & +++ & - & - & - \\
Bas1 & - & +++ & - & - \\
Bas2 & - & +++ & - & - \\
Bas3 & +++ & +++ & - & - \\
Bas4 & - & +++ & - & - \\
Bas5 & + & +++ & - & - \\
Bas6 & +++ & +++ & - & - \\
Bas7 & - & +++ & - & - \\
Bas8 & +++ & +++ & - & - \\
Bas9 & ++ & +++ & - & - \\
Bas10 & - & - & - & - \\
Bas11 & - & ++ & + & - \\
\hline Apampilln & & + &
\end{tabular}

Ap ampicillin, $\mathrm{Sm}$ streptomycin, $\mathrm{Cm}$ chloramphenicol, $\mathrm{Km}$ kanamycin, +++ very good growth, ++ good growth, + low growth, - no growth it could grow on both selected antibiotics, while fusant Bas6-1 could grow only with streptomycin.

\section{Chitinase activity}

Solid-state fermentation (SSF) experiments, with wheat bran as the most popular substrate in SSF enzyme production (Lonsane et al. 1985) and chitin powder, were applied to induce growth and production of chitinase by the selected bacterial strains. Under SSF conditions, the chitinase activities were much higher than those obtained under submerged fermentation (SmF) conditions (Table 2). The reduction in chitinase production under SmF conditions may be due to change in particle structure, reduction of gas volume, impaired oxygen transfer, and decreased diffusion (Babu and Satyanarayana 1996). All fusants and L. sphaericus had more chitinase activities under SSF than SmF condition (Table 2). The highest chitinase producer was fusant Bas8. Results showed also that Bas 6-2 had the lowest chitinase activity among the tested fusants, which is more probably due to different genetic background in this fusant. Fusants Bas 8 and Bas 3 were the highest chitinase producers (in descending order), whether under SSF or SmF cultivation conditions, on the one hand, and nematicidal activity, on the other hand. In the molecular mechanisms of nematophagous fungi infecting their hosts, it was suggested that hydrolytic enzymes participate in several steps of host infection. Moreover, ultrastructural and histochemical studies revealed that penetration of the nematode cuticle involves the activity of hydrolytic enzymes (Qiuhong et al. 2006).

\section{Effects of bacterial strains on $M$. incognita $\mathrm{J}_{2}$ mortality}

All fusants were more promising in killing $M$. incognita $\mathrm{J}_{2}$. The average percentage mortality recorded after $24 \mathrm{~h}$ as compared to control were $70.85,84.69,95.56$, $94.99,100$, and $89.46 \%$ due to the exposure to the suspensions of $B$. amyloliquefaciens, $L$. sphaericus, and fusants Bas3, Bas6-2, Bas8, and Bas11, respectively.

\section{Nematicidal potential of bacterial strains against Meloidogyne incognita infecting tomato plants}

Under greenhouse conditions, the three bacterial strains significantly $(P \leq 0.05)$ suppressed $M$. incognita reproduction by reducing the numbers of $\mathrm{J}_{2}$ in soil, galls, and egg masses in tomato roots as compared to untreated infected plants (Table 3). Fusant Bas 8 was more effective in suppressing $M$. incognita $\mathrm{J}_{2}$ in the soil by 72.68 , followed by $L$. sphaericus and then B. amyloliquefaciens, which resulted in 42.05 and $34.33 \%$ reduction, respectively, while the combination of the parental strains induced only $39.69 \%$ reduction as compared to control. The same trend was observed in a number of root galls and egg masses. The percentage reductions in 
Table 2 Chitinase activities produced by Bacillus amyloliquefaciens, Lysinibacillus sphaericus, and their fusants, grown under SSF and SmF fermentation conditions (Unit: $\mu \mathrm{g}$ NAG $\mathrm{ml}^{-1}$ enzyme $\mathrm{h}^{-1}$ )

\begin{tabular}{lllllll}
\hline Fermentation condition & Bacillus amyloliquefaciens & Lysinibacillus sphaericus & Fusant Bas3 & Fusant Bas6-2 & Fusant Bas8 & Fusant Bas11 \\
\hline SSF & 0 & 1393 & 3143 & 77 & 3399 & 851 \\
SmF & 90 & 85 & 118 & 15 & 143 & 98 \\
\hline
\end{tabular}

SSF solid-state fermentation, SmF submerged fermentation

root galls due to the previous suspensions were 58.36, $41.28,35.59$, and $36.30 \%$, respectively, while the percentage reductions recorded in egg masses due to the same treatments were 55.34, 0.97, 23.30, and 44.66\%, respectively. It is clear that there was no synergistic effect between the parents (Table 3). The impact of bacterial strain suspension on tomato plant growth parameters was recorded in Table 4. Significant differences between treatments were recorded in plant growth parameters. The fusant Bas 8 gave the best results in shoot length, fresh and dry weights, and root length.

The bacteria antagonistic to plant parasitic nematode in the rhizosphere provide the frontline defense for roots against nematode attack (Yang et al. 2013). They act by producing toxins and enzymes that suppress nematode reproduction, egg hatching, and juvenile survival, as well as direct killing of nematodes (Siddiqui and Mahmood 1999). Different attempts had used the protoplast fusion technique to obtain more efficient nematicidal bacterial strains as reported by El-Hamshary et al. (2006); the intrageneric fusants between Pseudomonas fluorescens and $P$. aeruginosa were more effective than its parental strains in reducing nematode as well as enhancing plant growth. Also, the intergeneric fusants between Serratia and Pseudomonas induced high mortality levels against M. incognita (Zaied et al. 2009). The present data revealed that the intergeneric protoplast fusion technique between $B$. amyloliquefaciens and $L$. sphaericus enhanced the production of the enzyme chitinase which increased the percentage mortality of $M$. incognita $\mathrm{J}_{2}$. In accordance with nematicidal activities, Bas 8 which produced high chitinase induced complete mortality of $M$. incognita $\mathrm{J}_{2}$ in in vitro test after $24 \mathrm{~h}$. Under greenhouse conditions, Bas 8 resulted in the higher decrease in nematode reproduction on tomato plants than its parents singly or in combination and increased tomato plant growth parameters as compared to control. These are in agreement with the findings of Mercer et al. (1992) who reported that chitinase interfered with the hatching of Meloidogyne sp. eggs resulting in the early emergence of juveniles that were less able to survive in soil. Woo-Jin et al. (2002) found that the chitinase produced by Paenibacillus illinoisensis caused lysis of $M$. incognita eggshell and resulted in the inhibition of egg hatching. Also, the increased activity of Bas 8 to suppress $M$. incognita infecting tomato plants refers to the ability of $L$. sphaericus to induce systemic resistance (HaskyGunther et al. 1998) and the production of the antibiotics and the siderophores (Almaghrabi et al. 2013). The increase in tomato plant growth parameters may refer to the extracellular phytase activity of $B$. amyloliquefaciens and the biological nitrogen fixation by $L$. sphaericus as reported by Idriss et al. (2002) and Zakry et al. (2012).

In the present study, different yields of chitinase productions resulted from SSF and SmF cultivation conditions might be due to wheat bran composition, which can affect one or more co-factors concerning chitinase production that differ according to bacterial strain as suggested by Qiuhong et al. (2006). Since, enzymes need, generally, non-protein compounds, such as metal ions, in doing their catalytic function (Natsir et al. 2010). Those compounds required by the enzymes as components in their active sites as activators or inhibitors in catalyzing the substrate at the certain concentration. Hence, Toharisman et al. (2002) and Natsir et al. (2010) showed that chitinase activities of some Bacillus strains were activated by $1 \mathrm{mM}$ of divalent ions $\left(\mathrm{Ca}^{2+}\right.$, $\mathrm{Mg}^{2+}$, and $\left.\mathrm{Mg}^{2+}\right)$.

\section{Conclusions}

In conclusion, the protoplast fusion is a used technique which produces genetically engineered microbial strains

Table 3 Nematicidal effect of bacterial strains against Meloidogyne incognita infecting tomato plants

\begin{tabular}{|c|c|c|c|c|c|c|}
\hline \multirow[t]{2}{*}{ Treatments } & \multicolumn{6}{|c|}{ Meloidogyne incognita parameters } \\
\hline & $\mathrm{J}_{2}$ in soil & $\%$ Red. & Galls/plant & $\%$ Red. & Egg masses/plant & $\%$ Red. \\
\hline Fusant Bas8 & $347^{c}$ & 72.68 & $117^{c}$ & 58.36 & $92^{c}$ & 55.34 \\
\hline B. amyloliquefaciens & $834^{\mathrm{b}}$ & 34.33 & $165^{\mathrm{b}}$ & 41.28 & $204^{\mathrm{a}}$ & 0.97 \\
\hline L. sphaericus & $736^{\mathrm{b}}$ & 42.05 & $181^{\mathrm{b}}$ & 35.59 & $158^{\mathrm{b}}$ & 23.30 \\
\hline B. amyloliquefaciens + L. sphaericus & $766^{\mathrm{b}}$ & 39.69 & $179^{\mathrm{b}}$ & 36.30 & $114^{\mathrm{c}}$ & 44.66 \\
\hline Control (untreated) & $1270^{\mathrm{a}}$ & - & $281^{a}$ & - & $206^{\mathrm{a}}$ & - \\
\hline
\end{tabular}

Means followed by the same letter are not significantly different by Duncan's multiple range test $(P \leq 0.05)$ 
Table 4 Effect of bacterial strains on tomato plant growth parameters

\begin{tabular}{|c|c|c|c|c|}
\hline \multirow[t]{2}{*}{ Treatments } & \multicolumn{2}{|c|}{ Shoot parameters } & \multicolumn{2}{|c|}{ Root parameters } \\
\hline & $\begin{array}{l}\text { Length } \\
(\mathrm{cm})\end{array}$ & $\begin{array}{l}\text { Fresh weight } \\
\text { (g) }\end{array}$ & $\begin{array}{l}\text { Dry weight } \\
\text { (g) }\end{array}$ & $\begin{array}{l}\text { Length } \\
(\mathrm{cm})\end{array}$ \\
\hline Fusant Bas8 & $33^{\mathrm{a}}$ & $13.51^{a}$ & $3.93^{\mathrm{a}}$ & $19.33^{a}$ \\
\hline B. amyloliquefaciens & $28.25^{\mathrm{ab}}$ & $14.04^{\mathrm{a}}$ & $4.00^{\mathrm{a}}$ & $19.00^{\mathrm{a}}$ \\
\hline L. sphaericus & $27.5^{b}$ & $10.64^{\mathrm{ab}}$ & $2.19^{\mathrm{b}}$ & $17.75^{\mathrm{ab}}$ \\
\hline $\begin{array}{l}\text { B. amyloliquefaciens }+ \\
\text { L. sphaericus }\end{array}$ & $31^{\mathrm{ab}}$ & $8.60^{b}$ & $1.51^{\mathrm{ab}}$ & $17.75^{\mathrm{ab}}$ \\
\hline Control (untreated) & $30.5^{\mathrm{ab}}$ & $11.84^{\mathrm{ab}}$ & $2.24^{b}$ & $16.5^{\mathrm{b}}$ \\
\hline
\end{tabular}

Means followed by the same letter are not significantly different by Duncan's multiple range test $(P \leq 0.05)$

harboring desirable biocontrol or biofertilizer properties in a single organism which in turn reflects better control of plant parasitic nematodes and increased yield production. On the other hand, optimization of the hydrolytic enzyme chitinase production by bacterial strains is vital; since, a relation between both activities was observed. The obtained data indicated that fusant from B. amyloliquefaciens and L. sphaericus could be used as biological control agents against root-knot nematode $M$. incognita.

\section{Acknowledgements}

This work was funded by a grant code number 10120603 of in-house project from the National Research Centre, Giza, Egypt.

\section{Financial support}

Nil.

\section{Authors' contributions}

MSA-S and HHA conceived the work. MSA-S, GMS and USE carreid out the molecular genetic studies. AMA study the production of the chitinase enzyme. MSA-S, GMS and USE participate in the sequence alignment. MSA-S, HHA and AMA drafted the manuscript. HHA write the final manuscript. All authors read and approved the final manuscript.

\section{Competing interests}

The authors declare that they have no competing interests.

\section{Publisher's Note}

Springer Nature remains neutral with regard to jurisdictional claims in published maps and institutional affiliations.

\section{Author details}

${ }^{1}$ Microbial Genetics Department, National Research Centre, Giza, Egypt. ${ }^{2}$ Plant Pathology Department, National Research Centre, Giza, Egypt. ${ }^{3}$ Microbial Chemistry Department, National Research Centre, Giza, Egypt.

Received: 10 November 2017 Accepted: 31 January 2018 Published online: 22 March 2018

\section{References}

Almaghrabi OA, Mohamed SI, Abdelmoneim TS (2013) Influence of inoculation with plant growth promoting rhizobacteria (PGPR) on tomato plant growth and nematode reproduction under greenhouse conditions. Saudi J. of Biological Sciences 20:57-61

Babu KR, Satyanarayana T (1996) Production of bacterial enzymes by solid state fermentation. J Sci Ind Res 55:464-467
Becker JO, Zavaleta-mejia E, Colbert SF, Schroth MN, Weinhold AR, Hancock JG, Van Gundy SD (1988) The effect of rhizobacteria on root-knot nematode and gall formation. Phytopathology 78:1466-1469

Chitwood D (2003) Research on plant parasitic nematodes biology conducted by United States Department of Agriculture. Agriculture Research Service. Pest Manag Sci 59:748-753

Davis RW, Botstein D, Rotho JR (1980) Transfection of DNA. In bacterial genetics: a manual for genetic engineering advanced bacterial genetic, vol 67. Cold Spring Harbor laboratory cold spring harbor, New York, pp 134-137

Duncan DB (1955) Multiple ranges and multiple F test. Biometrics 11:11-24

Eisa EG, Akao S, Kitamoto Y (1995) Enhanced nitrogen fixation capabilities of soybean rhizobia by inter and intra-specific cell fusion. Jpn. J Crop Sci 64(2):273-280

El-Hamshary OIM, El-Nagdi WMA, Youssef MMA (2006) Genetical studies and antagonistic effects of a newly bacterial fusant against Meloidogyne incognita, root-knot nematode and a plant pathogen Fusarium oxysporum infecting sunflower. Pak J Biotechnol 3(1-2):61-70

Hasky-Gunther K, Hoffmann-Hergarten S, Sikora RA (1998) Resistance against the potato cyst nematode Globodera pallida systemically induced by the rhizobacteria Agrobacterium radiobacter (G12) and Bacillus sphaericus (B43). Fundam Appl Nematol 21:511-517

Hopwood DA, Bibb MJ, Chater KF, Kieser T, Bruton CJ, Kieser HM, Lydiate DJ, Smith CP, Ward JM, Schrempt H (1985) Genetic manipulation of Streptomyces-a laboratory manual. The John Innes Foundation, Norwick

Hussey RS, Barker KR (1973) A comparison of methods of collecting inocula of Meloidogyne spp., including a new technique. Plant Disease Reporter 57: 1025-1028

Ibrahim SA, Abdel-Salam MS, Abd El-Halim MM, Bahy-Edin A, Abo-Aba SE (1998) Transfer and expression of nodulation genes in Agrobacterium tumefaciens. Proceeding of the Third Arab Conference on Modern Biotechnology and Areas of Application in the Arab World, Cairo, pp 14-17

Idriss EE, Makarewicz O, Farouk A, Rosner K, Greiner R, Bochow, Borriss R (2002) Extracellular phytase activity of Bacillus amyloliquefaciens FZB45 contributes to its plant-growth-promoting effect. Microbiology 148(7):2097-2109

Lonsane BK, Ghildyal NP, Budiatman S, Ramakrishna SV (1985) Engineering aspects of solid-state fermentation. Enzym Microb Technol 7:258-265

Mercer CF, Greenwood DR, Grant JL (1992) Effect of plant and microbial chitinases on the eggs and juveniles of Meloidogyne hapla Chitwood. Nematologica 38:227-236

Natsir H, Ptong AR, Suhartono MT, Ahmad A (2010) Production and characterization of chitinase enzymes from Sulili hot spring in South Sulawesi, Bacillus sp. HAS,3-1a. Indo J Chem 10(2):263-267

Qiuhong N, Xioewei H, Baoyu T, Jinkin Y, Jiang L, Lin Z, Keqin Z. (2006) Bacillus sp. B16 kills nematodes with a serine protease identified as a pathogenic factor. Appl Microbial Biotechnol 69:722-730

Saharan BS, Nehra V (2011) Plant growth promoting Rhizobacteria: a critical review. Life Sciences and Medicine Research:1-30 LSMR-21

Schisler DA, Slininger PJ, Bothast RJ (1997) Effects of antagonist cell concentration and two-strain mixtures on biological control of Fusarium dry rot of potatoes. Phytopathology 87:177-183

Siddiqui ZA, Mahmood I (1999) Role of bacteria in the management of plant parasitic nematodes: a review. Bioresour Technol 69:167-179

Sudhakar P, Nagarajan P (2010) Production of chitinase by solid state fermentation from rice bran. Intern J. EB-2. The $5^{\text {th }}$ JSPS International, Seminar, Marine Product Processing Technology, Bogor:20-21

Toharism A, Suhartona MT, Hwang J K, Pyung YR (2002) Thermostable chitinase from Bacillus licheniformius MB-2. The 5 JSPS International Seminar, Marine Product Processing Technology, Bogor: 20-21

Tunga R, Banerjee R, Bhattacharya BC (1998) Optimizing some factors affecting protease production under solid-state fermentation. Bioprocess Eng 19:187-190

Woo-Jin J, Soon-Ju J, Kyu-Nam A, Yu-Lan J, Ro-Dong P, Kil-Yong K, Bo-Kyoon S, Tae-Hwan K (2002) Effect of chitinase-producing Baenibacillus illinoisensis KJA 424 on egg hatching of root knot nematode (Meloidogyne incognita). Journal of Microbiol Biotechnol 12(6):865-871

Yang J, Liang L, Li J, Zhang K (2013) Nematicidal enzymes from microorganisms and their applications. Appl Microbiol Biotechnol 97:7081-7095

Zaied KA, Kawther S, Kash S, Ibrahim A, Tawfik TM (2009) Improving nematocidial activity of bacteria via protoplast fusion. Aust J Basic Appl Sci 3(2):1412-1427

Zakry FA, Shamsuddin H, Zulkifli R, Khairuddin A, Zakaria Z, Rahim AA (2012) Inoculation of Bacillus sphaericus UPMB-10 to young oil palm and measurement of its uptake of fixed nitrogen using the $15 \mathrm{~N}$ isotope dilution. Technique Microbes Environ 27(3):257-262 